This item was submitted to Loughborough's Research Repository by the author.

Items in Figshare are protected by copyright, with all rights reserved, unless otherwise indicated.

\title{
Foreword to 5th International Conference on Whole Body Vibration Injuries held at Academic Medical Center, University of Amsterdam, The Netherlands, 5-7 June 2013
}

\section{PLEASE CITE THE PUBLISHED VERSION}

http://dx.doi.org/10.1080/00140139.2015.1039226

\section{PUBLISHER}

(C) Taylor \& Francis

\section{VERSION}

AM (Accepted Manuscript)

\section{PUBLISHER STATEMENT}

This work is made available according to the conditions of the Creative Commons Attribution-NonCommercialNoDerivatives 4.0 International (CC BY-NC-ND 4.0) licence. Full details of this licence are available at: https://creativecommons.org/licenses/by-nc-nd/4.0/

\section{LICENCE}

CC BY-NC-ND 4.0

\section{REPOSITORY RECORD}

Mansfield, Neil J., and Carel T.J. Hulshof. 2019. "Foreword to 5th International Conference on Whole Body Vibration Injuries Held at Academic Medical Center, University of Amsterdam, the Netherlands, 5-7 June 2013". figshare. https://hdl.handle.net/2134/17328. 


\section{Guest editorial}

\section{Foreword to 5th International Conference on Whole Body Vibration Injuries held at Academic Medical Center, University of Amsterdam, The Netherlands, 5-7 June 2013}

Low back pain (LBP) and back disorders are among the most common and costly occupational health problems. Occupational, non-occupational, and individual risk factors play a role in the development, the duration, and the recurrence of LBP. One of the occupational factors is the exposure to whole body vibration (WBV) at work. Whether this exposure is only a modest or a substantial risk factor for the onset and recurrence of LBP is still a matter of debate. Nevertheless, in a number of European countries LBP and back disorders due to WBV are, when meeting specific criteria, currently recognised as an occupational disease. High exposures still occur as WBV is a common occupational risk factor, affecting $4 \%$ to $8 \%$ of the workforce in industrialised countries. Occupational exposures to levels of whole-body vibration and mechanical shock that may be hazardous for safety and health of workers still occur in many countries. Therefore, joint actions in research and practice are encouraged. The $5^{\text {th }}$ International Conference on Whole Body Vibration Injuries offered an opportunity for this.

This multi-disciplinary conference was organised by the Coronel Institute of Occupational Health, Academic Medical Center, University of Amsterdam and was held from 5-7 June 2013. The chair of the local organising committee was Prof. Dr Carel TJ Hulshof (Coronel Institute).

The conference has been running since the 1990s and occurs on an approximate 4-year cycle. Previous conferences have been held in Southampton UK (1997), Siena Italy (2000), Nancy France (2005), and Montreal Canada (2009). Following each conference selected papers were published in special issues of peer reviewed journals that have proven to become valuable repositories summarising the state of research in the field of whole-body vibration injuries at that time.

Being multi-disciplinary, the conference provides an opportunity for stakeholders to discuss current thinking from a range of perspectives. The 2013 conference included researchers, policy makers, practitioners, trade representatives, equipment manufacturers and regulators from 16 different countries across the world.

In six keynote lectures, 10 oral paper sessions, and a poster session, in total 44 papers were presented at the conference in the areas of occupational disease, mathematical modelling of seats, biomechanics, epidemiology, measurement of vibration, preventative measures, and guidelines and standards. Each conference paper had three keywords, and these have been collated into a word cloud, with frequency of use associated with text size (Figure 1). In the tradition of the meeting, it concluded with an open discussion to identify the key lessons that have been learned, where there remains disagreement amongst experts, current challenges in research and where the field should head in the future. 


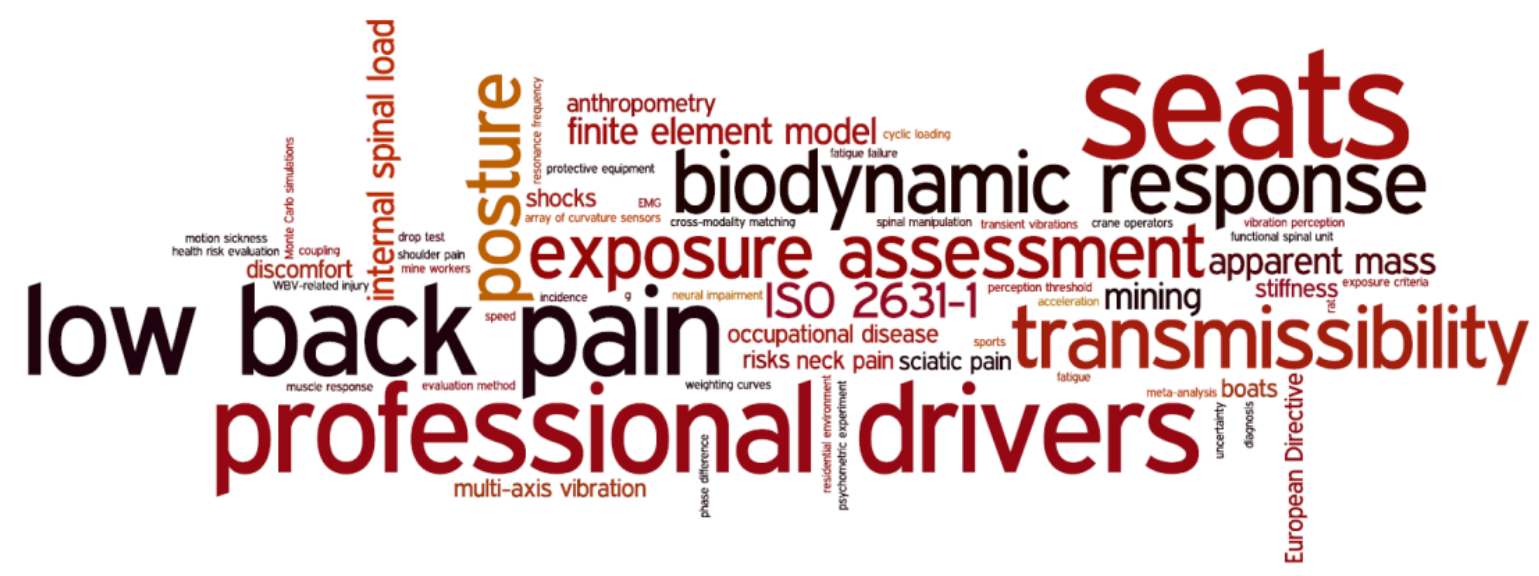

Figure 1. Word cloud generated from keywords associated with papers presented at 5th International Conference on Whole Body Vibration Injuries.

14 papers have been accepted for publication in this special issue of Ergonomics. Each of these has undergone rigorous review and on behalf of the authors the guest editors would like to express their thanks to the many anonymous peer reviewers who have helped ensure that this special issue is as high quality and valuable as those from previous conferences.

\section{Guest editors}

Neil J Mansfield, Loughborough Design School, Loughborough University

Carel TJ Hulshof, Coronel Institute of Occupational Health, Academic Medical Center, University of Amsterdam 